\title{
Frequency and intensity of nitrogen addition alter soil inorganic sulfur fractions, but the effects vary with mowing management in a temperate steppe
}

\author{
Tianpeng $\mathrm{Li}^{1,{ }^{*}}$, Heyong Liu ${ }^{2,{ }^{*}}$, Ruzhen Wang ${ }^{1}$, Xiao-Tao Lü̈${ }^{1}$, Junjie Yang ${ }^{3}$, Yunhai Zhang ${ }^{3}$, Peng He ${ }^{1}$, Zhirui Wang ${ }^{1}$, \\ Xingguo $\mathrm{Han}^{3}$, and Yong Jiang ${ }^{1}$ \\ ${ }^{1}$ Institute of Applied Ecology, Chinese Academy of Sciences, Shenyang 110016, China \\ ${ }^{2}$ College of Land and Environment, Shenyang Agricultural University, Shenyang 110866, China \\ ${ }^{3}$ State Key Laboratory of Vegetation and Environmental Change, Institute of Botany, \\ Chinese Academy of Sciences, Beijing 100093, China \\ * These authors contributed equally to this work.
}

Correspondence: Ruzhen Wang (ruzhenwang@iae.ac.cn) and Yong Jiang (jiangyong@iae.ac.cn)

Received: 25 December 2018 - Discussion started: 1 February 2019

Revised: 25 June 2019 - Accepted: 4 July 2019 - Published: 31 July 2019

\begin{abstract}
Sulfur (S) availability plays a vital role in driving functions of terrestrial ecosystems, which can be largely affected by soil inorganic $\mathrm{S}$ fractions and pool size. Enhanced nitrogen $(\mathrm{N})$ input can significantly affect soil $\mathrm{S}$ availability, but it still remains largely unknown if the $\mathrm{N}$ effect varies with frequency of $\mathrm{N}$ addition and mowing management in grasslands. To investigate changes in the soil $\mathrm{S}$ pool and inorganic $\mathrm{S}$ fractions (soluble $\mathrm{S}$, adsorbed $\mathrm{S}$, available $\mathrm{S}$, and insoluble $S$ ), we conducted a field experiment with different frequencies (two times per year vs. monthly additions per year) and intensities (i.e., 0, 1, 2, 3, 5, 10, 15, 20, and $50 \mathrm{~g} \mathrm{~N} \mathrm{~m}^{-2} \mathrm{yr}^{-1}$ ) of $\mathrm{NH}_{4} \mathrm{NO}_{3}$ addition and mowing (unmown vs. mown) over 6 years in a temperate grassland of northern China. Generally, $\mathrm{N}$ addition frequency, $\mathrm{N}$ intensity, and mowing significantly interacted with each other to affect most of the inorganic $\mathrm{S}$ fractions. Specifically, a significant increase in soluble $\mathrm{S}$ was only found at high $\mathrm{N}$ frequency with the increasing intensity of $\mathrm{N}$ addition. Increasing $\mathrm{N}$ addition intensity enhanced adsorbed $\mathrm{S}$ and available $\mathrm{S}$ concentrations at low $\mathrm{N}$ frequency in unmown plots; however, both fractions were significantly increased with $\mathrm{N}$ intensity at both $\mathrm{N}$ frequencies in mown plots. The high frequency of $\mathrm{N}$ addition increased the concentrations of adsorbed $\mathrm{S}$ and available $\mathrm{S}$ in comparison to the low frequency of $\mathrm{N}$ addition only in mown plots. Changes in soil $\mathrm{S}$ fractions were mainly related to soil $\mathrm{pH}$, $\mathrm{N}$ availability, soil organic carbon (SOC), and plant $\mathrm{S}$ uptake. Our results suggested that $\mathrm{N}$ input could temporarily
\end{abstract}

replenish soil-available $\mathrm{S}$ by promoting dissolution of soilinsoluble $\mathrm{S}$ with decreasing soil $\mathrm{pH}$ and mineralization of organic $\mathrm{S}$ due to increasing plant $\mathrm{S}$ uptake. However, the significant decrease in organic $\mathrm{S}$ and total $\mathrm{S}$ concentrations with $\mathrm{N}$ addition intensity in mown plots indicated that $\mathrm{N}$ addition together with biomass removal would eventually cause soil $\mathrm{S}$ depletion in this temperate grassland in the long term. Our results further indicated that using large and infrequent $\mathrm{N}$ additions to simulate $\mathrm{N}$ deposition can overestimate the main effects of $\mathrm{N}$ deposition and mowing management on soil $\mathrm{S}$ availability in semiarid grasslands.

\section{Introduction}

Sulfur (S) is an essential nutrient for the metabolism of plants and soil microorganisms by constituting amino acids of cysteine and methionine (Blum et al., 2013). It also plays vital roles in increasing plant nitrogen $(\mathrm{N})$ use efficiency, enhancing crop yield and quality (De Bona and Monteiro, 2010), and reducing plant diseases and heavy metal toxicity (Chiang et al., 2006; Feechan et al., 2005). Plant S deficiency is widely distributed in global ecosystems (Kost et al., 2008; Scherer, 2009), with negative effects on stomatal conductance, photosynthetic rate, and consequently primary productivity (Juszczuk and Ostaszewska, 2011; Wulff- 
Zottele et al., 2010). As a macronutrient for plants, S occurs in soils in both organic and inorganic forms. Soil organic $\mathrm{S}$ includes ester-bonded $\mathrm{S}, \mathrm{C}$-bonded $\mathrm{S}$, and residual $\mathrm{S}$, with the first two forms constituting the potential S source for plants. Inorganic S, accounting for approximately $5 \%$ of total soil S in mostly temperate soils (Tabatabai, 2005), generally occurs as bioavailable $\mathrm{S}$ (including soluble $\mathrm{SO}_{4}^{2-}$ and adsorbed $\mathrm{SO}_{4}^{2-}$ ) and insoluble $\mathrm{S}\left(\mathrm{SO}_{4}^{2-}\right.$ coprecipitated with $\mathrm{CaCO}_{3}$ or co-crystallization with cations) (Fig. 1; Tisdale et al., 1993). Soluble $\mathrm{S}$ is the most active fraction with high mobility in soil pore water and prone to leaching loss (Fig. 1), while $\mathrm{S}$ adsorption helps to retain $\mathrm{SO}_{4}^{2-}$ from hydrologic leaching (Riscassi et al., 2019). Transformations of inorganic $\mathrm{S}$ fractions govern soil $\mathrm{S}$ availability which are closely associated with plant-soil interactions (Kertesz and Mirleau, 2004; Juszczuk and Ostaszewska, 2011). For instance, the reversible processes of both $\mathrm{S}$ adsorption and dissolution (Fig. 1) are pH dependent (McGill and Cole, 1981; Tabatabai, 2005) and can be accelerated or decelerated by microbial S immobilization and plant $\mathrm{S}$ demand. Therefore, changes in the soil inorganic $S$ pool play a major role in $S$ dynamics, which can further impact the mineralization of organic S and plant growth (Kertesz and Mirleau, 2004). A deeper understanding of transport and transformation of soil inorganic $\mathrm{S}$ fractions is essential for better predicting $\mathrm{S}$ supply to plants under global change scenarios.

As they are mainly caused by increasing atmospheric $\mathrm{N}$ deposition and fertilization, enhanced $\mathrm{N}$ inputs result in severe ecological problems in temperate ecosystems worldwide (Bobbink et al., 2010), which are predicted to deteriorate in the coming decades, especially in developing countries (Dentener et al., 2006). Higher $\mathrm{N}$ input may increase plant $\mathrm{S}$ uptake and affect soil $\mathrm{S}$ turnover by enhancing primary productivity, especially in $\mathrm{N}$-limited regions (De Bona and Monteiro, 2010; Harpole et al., 2007; Phoenix et al., 2012; Wang et al., 2015). Nitrogen input can promote S supply by stimulating the mineralization of C-bonded $\mathrm{S}$ (into the form of $\mathrm{SO}_{4}^{2-}-\mathrm{S}$ ) (De Bona and Monteiro, 2010) and abiotic dissolution of mineral-bound $\mathrm{S}$ under the $\mathrm{N}$-induced soil acidification (Wang et al., 2016). However, results from an 80-year fertilization experiment showed that $\mathrm{N}$ addition did not change the concentrations of soil inorganic and organic S (Yang et al., 2007). Nitrogen inputs may have negative effects on $\mathrm{S}$ cycling rate due to the inhibition of arylsulfatase activity (Chen et al., 2016). Therefore, soil S availability is mainly associated with soil $\mathrm{pH}$ and mineralization of soil organic matter (SOM) under $\mathrm{N}$ enrichment, but it is still poorly understood for its relationship with inorganic $\mathrm{S}$ fractions.

Studies simulating $\mathrm{N}$ deposition commonly add $\mathrm{N}$ as an intensive and pulsed input (Smith et al., 2009). However, natural $\mathrm{N}$ deposition occurs more frequently and evenly in small events (Aneja et al., 2001). Low frequency of $\mathrm{N}$ addition increases plant biomass (Barton et al., 2008; Bilbrough and Caldwell, 1997) and ammonia volatilization (Zhang et al., 2014a) but decreases soil pH (Wang et al., 2018) and plant $\mathrm{N}$ concentrations (Cheng et al., 2009) in comparison to highfrequency $\mathrm{N}$ addition. Low frequency of $\mathrm{N}$ addition has been reported to overestimate the effects of $\mathrm{N}$ deposition on plant species diversity (Zhang et al., 2014b). Therefore, lower soil $\mathrm{pH}$ and enhanced plant biomass could possibly promote inorganic S dissolution and plant $\mathrm{S}$ retention under low frequency of $\mathrm{N}$ addition. Though these studies demonstrated that $\mathrm{N}$ input frequencies alter factors associated with transformation of soil $\mathrm{S}$ fractions (i.e., soil $\mathrm{pH}$ and plant uptake), how $\mathrm{N}$ input frequency influences transformation of soil inorganic $S$ fractions still remains largely unknown.

Mowing is a common management practice for hay harvesting in temperate grasslands (Bremer and Ham, 2002; Zhang et al., 2017a), which greatly reduces nutrient return from plant residues (Janzen and Ellert, 1998). Persistent harvesting and mowing could reduce the incorporation of plant $\mathrm{S}$ into soil, breaking the natural cycling of $\mathrm{S}$ and thus causing the depletion of soil inorganic S (Solomon et al., 2001). Moreover, mowing can alter soil S mineralization and immobilization by changing soil moisture, microbial activity, and plant biomass allocation (Barrow, 1960). Under N-enriched conditions, mowing would aggravate depletion of soil S pool by removing more plant biomass and plant $\mathrm{S}$ out of the ecosystems in comparison to ambient $\mathrm{N}$ conditions. The effects of biomass removal on soil inorganic $\mathrm{S}$ fractions remain poorly understood, while, to our knowledge, the interactive $\mathrm{N}$-mowing effect has not been explored in temperate grassland ecosystems.

Temperate grasslands, which account for $8 \%$ of the earth's land surface (White et al., 2000) with important ecological function and economic value, play an important role in the global S cycle. Primary productivity of temperate grasslands is mainly limited by $\mathrm{N}$ availability and typically sensitive to $\mathrm{N}$ input (Niu et al., 2010; Yang et al., 2012). Low background $\mathrm{N}$ deposition in temperate grasslands of Inner Mongolia $\left(<1.5 \mathrm{~g} \mathrm{~N} \mathrm{~m}^{-2} \mathrm{yr}^{-1}\right)$ makes this area an ideal place to investigate ecosystem responses to $\mathrm{N}$ enrichment (Zhao et al., 2017). For a better understanding of soil S supply and turnover under mowing and different intensities and frequencies of $\mathrm{N}$ addition, a field experiment was conducted to investigate soil inorganic $\mathrm{S}$ fractions and their transformations in a temperate steppe of Inner Mongolia. We hypothesized that (1) a higher intensity of $\mathrm{N}$ addition would increase available $\mathrm{S}$ (soluble $\mathrm{S}$ and adsorbed $\mathrm{S}$ ) concentration by promoting insoluble $\mathrm{S}$ dissolution with a drop in soil $\mathrm{pH}$ and enhancement of plant residue return and organic S mineralization; (2) the increase in available $S$ and decrease in insoluble $S$ would be more pronounced with a low frequency of $\mathrm{N}$ addition due to lower soil $\mathrm{pH}$ conditions than the high frequency of $\mathrm{N}$ addition; (3) mowing would decrease soil inorganic $\mathrm{S}$ fractions resulting from reduced plant residue return, and such effects would be exacerbated with increasing $\mathrm{N}$ addition intensities due to enhanced plant $S$ retention. 


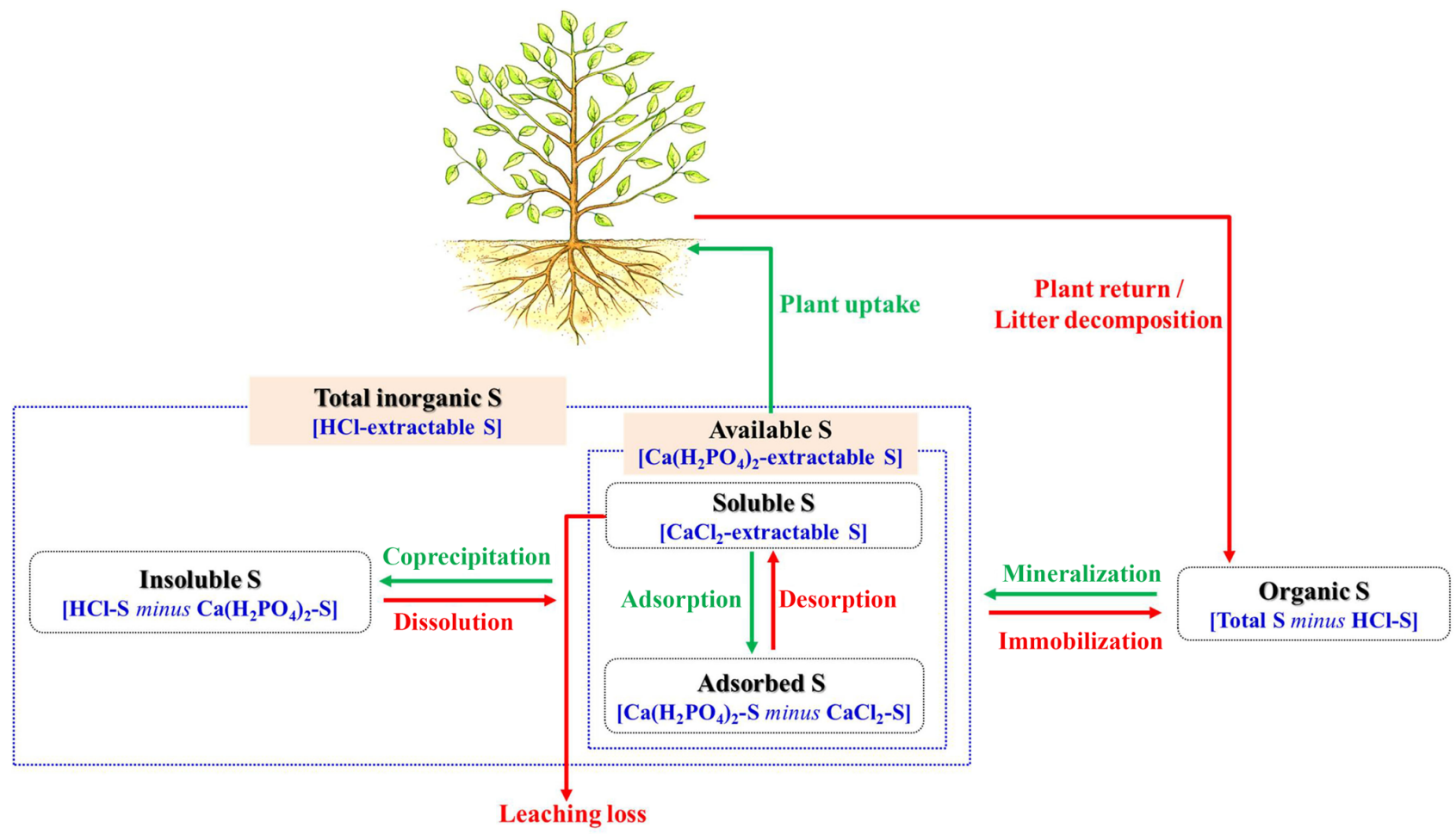

Figure 1. Conceptual scheme depicting the transformation of sulfur (S) fractions in aerobic calcareous soils. Arrows indicate processes affecting the concentration of one $\mathrm{S}$ fraction, with green and red colors representing opposite transformation processes. Below each $\mathrm{S}$ fraction, characters in blue indicate that the $\mathrm{S}$ fraction was directly measured from the extraction or indirectly calculated from analyzed fractions. Specifically, soluble $\mathrm{S}\left(\mathrm{CaCl}_{2}-\right)$, available $\mathrm{S}\left(\mathrm{Ca}\left(\mathrm{H}_{2} \mathrm{PO}_{4}\right)_{2}-\mathrm{S}\right)$, and total inorganic $\mathrm{S}(\mathrm{HCl}-\mathrm{S})$ were directly extracted by $\mathrm{CaCl}_{2}, \mathrm{Ca}_{2}\left(\mathrm{H}_{2} \mathrm{PO}_{4}\right)_{2}$, and $\mathrm{HCl}$, respectively. Adsorbed $\mathrm{S}$ was calculated by $\mathrm{Ca}\left(\mathrm{H}_{2} \mathrm{PO}_{4}\right)_{2}-\mathrm{S}$ minus $\mathrm{CaCl}_{2}-\mathrm{S}$, insoluble $\mathrm{S}$ by $\mathrm{HCl}-\mathrm{S}$ minus $\mathrm{Ca}\left(\mathrm{H}_{2} \mathrm{PO}\right)_{2}-\mathrm{S}$, and organic $\mathrm{S}$ by total $\mathrm{S}$ minus HCl-S.

\section{Materials and methods}

\subsection{Site description and experimental design}

The study site $\left(43^{\circ} 13^{\prime} \mathrm{N}, 116^{\circ} 14^{\prime} \mathrm{E}\right)$ is a typical temperate semiarid steppe at the Inner Mongolia Grassland Ecosystem Research Station (IMGERS) in the Xilin River watershed, Inner Mongolia, China. The mean annual air temperature is $0.9^{\circ} \mathrm{C}$, varying from $-21.4^{\circ} \mathrm{C}$ in January to $19.7^{\circ} \mathrm{C}$ in July. The long-term mean annual precipitation is $351.4 \mathrm{~mm}$, about $72.8 \%$ of which is concentrated from May to August, according to the data from 1980 to 2013 (monitored and provided by IMGERS). The steppe is dominated by Leymus chinensis, Stipa grandis, Agropyron cristatum, and Koeleria cristata. The soil was classified as a Haplic Calcisol by the Food and Agriculture Organization of the United Nations (FAO) soil classification system, with a depth of $100-150 \mathrm{~cm}$ and a composition of $21 \%$ clay, $60 \%$ sand, and $19 \%$ silt on average (Hao et al., 2013). The site has experienced an uncontrolled heavy sheep grazing since the 1980s and has been fenced since 1999. No fertilizer was applied before the experiment was conducted.
The experiment was set up in 2008 following a randomized block design. There were nine $\mathrm{N}$ addition intensities $(0$, $1,2,3,5,10,15,20$, and $\left.50 \mathrm{~g} \mathrm{~N} \mathrm{~m}^{-2} \mathrm{yr}^{-1}\right)$ crossed with two $\mathrm{N}$ addition frequencies ( 2 times per year vs. 12 times per year) and two mowing regimes (unmown and mown). Currently, infrequent $\mathrm{N}$ addition (i.e., one or two times per year) is commonly used in manipulative experiments to mimic $\mathrm{N}$ deposition, which is quite different from natural $\mathrm{N}$ deposition occurring continuously throughout the year (Smith et al., 2009). Therefore, a more frequent and even way of $\mathrm{N}$ addition (i.e., 12 times per year) was set to simulate natural $\mathrm{N}$ deposition (Aneja et al., 2001) and to compare whether the changing frequency of $\mathrm{N}$ input affects the grassland ecosystem. Higher rates of $\mathrm{N}$ addition were used to mimic accumulative $\mathrm{N}$ deposition in the long term and/or extreme $\mathrm{N}$ inputs in the future of the grassland (Zhang et al., 2017b). $\mathrm{NH}_{4} \mathrm{NO}_{3}(>99.5 \%)$ was added in wet and dry forms to simulate the wet and dry $\mathrm{N}$ deposition, respectively. For the high-frequency treatments, $\mathrm{NH}_{4} \mathrm{NO}_{3}$ was added monthly since 1 September 2008. For the low-frequency treatments, $\mathrm{NH}_{4} \mathrm{NO}_{3}$ was added each year on 1 June and November since November 2008. During the growing season (from May to October), $\mathrm{N}$ was added in wet form by mixing $\mathrm{NH}_{4} \mathrm{NO}_{3}$ with purified water $(9.0 \mathrm{~L}$ water 
in total for each plot, either $9.0 \mathrm{~L}$ once in June for low frequency or $1.5 \mathrm{~L}$ monthly from May to October for high frequency) and then sprayed evenly with a sprayer. To simulate dry $\mathrm{N}$ deposition in the nongrowing season, $\mathrm{NH}_{4} \mathrm{NO}_{3}$ was broadcast after being mixed with treated sand to ensure even fertilization. Specifically, $500 \mathrm{~g}$ of sand was used once in November for low-frequency treatments, and $80 \mathrm{~g}$ of sand was used monthly from November to the next April for highfrequency treatments and then broadcast evenly in every plot. The sand used in this experiment was sieved through a $1 \mathrm{~mm}$ sieve, dipped in hydrochloric acid, washed in purified water, and then oven dried at $120^{\circ} \mathrm{C}$ for $48 \mathrm{~h}$ to remove acidsoluble S. Annual mowing was conducted at the end of August using a hay mower at $10 \mathrm{~cm}$ height to simulate the local hay-cutting management. The aboveground plant residue was taken away immediately after mowing. We also set an unnamed control without any treatment ( $\mathrm{N}$ addition, mowing, water, or sand addition) to determine the impacts of water and sand addition, which were also compared with mowing treatment without any other treatments. Thus, there were 38 treatments with 10 replicate blocks for every treatment. Each plot is $8 \mathrm{~m} \times 8 \mathrm{~m}$ and separated by a $1 \mathrm{~m}$ buffer zone.

\subsection{Plant and soil sampling}

We assessed aboveground biomass in each plot by clipping a $1 \mathrm{~m} \times 1 \mathrm{~m}$ quadrat above soil surface in late August 2014. All the living plants were clipped and sorted by species, dried, and weighed. The plant samples were washed using deionized water and then dried to constant weight at $65^{\circ} \mathrm{C}$ for $48 \mathrm{~h}$.

Soil samples were collected from each of the 380 plots at the beginning of August 2014 (i.e., after 6 years of treatments). A mixed sample was taken randomly from five cores of the topsoil $(0$ to $10 \mathrm{~cm})$ within each plot. Then, samples were passed through a $2 \mathrm{~mm}$ sieve immediately to remove the plant residues and then air dried for further analysis.

\subsection{Measurement of soil chemical properties}

Soil $\mathrm{pH}$ was determined in a soil slurry at $2.5: 1(w / v)$ water/soil ratio by a digital $\mathrm{pH}$ meter (Precision and Scientific Instrument Co. Ltd., Shanghai, China) and the data are given in Table 1 reported by Wang et al. (2018). The concentration of soil organic carbon (SOC) in the topsoil was determined by oxidation using a mixture of $\mathrm{K}_{2} \mathrm{Cr}_{2} \mathrm{O}_{7}$ solution and sulfuric acid and titration using $\mathrm{FeSO}_{4}$ (Nelson and Sommers, 1982). Soil total inorganic nitrogen (TIN) concentration was calculated as the sum of ammonium and nitrate, which was extracted with $2 \mathrm{M} \mathrm{KCl}$ and determined using a continuous flowing analyzer $\left(\mathrm{SAN}^{++}\right.$segmented flow analyzer, Skalar, the Netherlands). Soil pH, SOC, and TIN were previously reported in Wang et al. (2018). Soil total sulfur (TS) concentration was analyzed with an elemental analyzer (Vario MACRO cube, Elementar Analysensysteme GmbH, Germany).
A schematic diagram is shown to illustrate the transformation processes and extraction and calculation procedures of the $\mathrm{S}$ fractions (Fig. 1). Soluble $\mathrm{S}$, available $\mathrm{S}$, and total inorganic $\mathrm{S}$ were extracted with $0.01 \mathrm{M} \mathrm{CaCl}_{2}, 0.01 \mathrm{M}$ $\mathrm{Ca}\left(\mathrm{H}_{2} \mathrm{PO}_{4}\right)_{2}$, and $1 \mathrm{M} \mathrm{HCl}$ at a $5: 1(w / v)$ water/soil ratio, respectively (Roberts and Bettany, 1985). Briefly, $5.0 \mathrm{~g}$ of the air-dried soil was mixed with $25 \mathrm{~mL}$ extractant and shaken at $400 \mathrm{rpm}$ for $60 \mathrm{~min}$ at $25^{\circ} \mathrm{C}$. The extracts were filtered and digested with $1 \mathrm{~mL}$ of $30 \% \mathrm{H}_{2} \mathrm{O}_{2}$ for $20 \mathrm{~min}$ to remove the color of soil organic matter. The $\mathrm{Ca}^{2+}$ in extractants of $\mathrm{CaCl}_{2}$ and $\mathrm{Ca}\left(\mathrm{H}_{2} \mathrm{PO}_{4}\right)_{2}$ can effectively depress the solubility of organic matter during the extraction. The cooled solutions were then mixed with $0.5 \mathrm{~mL}$ of $\mathrm{HCl}(1: 4)$ and $1 \mathrm{~mL}$ of gum acacia solution (to stabilize the suspension) successively and adjusted to $25 \mathrm{~mL}$. The $\mathrm{SO}_{4}^{2-}$ in all the extracts was quantified by turbidimetry with $0.5 \mathrm{~g}$ of $\mathrm{BaCl}_{2}$ crystals at $440 \mathrm{~nm}$ using a UV-VIS spectrophotometer (UV-1700, Shimadzu, Japan) (Tabatabai and Bremner, 1972). Adsorbed S, total inorganic $\mathrm{S}$, and organic $\mathrm{S}$ concentrations were calculated as follows:

adsorbed $\mathrm{S}=$ available $\mathrm{S}-$ soluble $\mathrm{S}$,

insoluble $\mathrm{S}=$ total inorganic $\mathrm{S}-$ available $\mathrm{S}$,

organic $S=$ total $S-$ total inorganic $S$.

We measured total $\mathrm{S}$ concentration in two dominant species of Leymus chinensis and Stipa grandis in $\mathrm{N}$ addition plots of 0 and $15 \mathrm{~g} \mathrm{~N} \mathrm{~m}^{-2} \mathrm{yr}^{-1}$ under low and high frequencies of $\mathrm{N}$ addition with and without mowing. Briefly, $0.3 \mathrm{~g}$ plant samples were acid digested with a $1: 2(v / v)$ mixture of $65 \%$ nitric acid and $72 \%$ perchloric acid at around $235^{\circ} \mathrm{C}$ (Soon et al., 1996). The $\mathrm{S}$ concentration of digestion solution was quantified by turbidimetry at $440 \mathrm{~nm}$ using a UVVIS spectrophotometer (UV-1700, Shimadzu, Tokyo, Japan). Plant S uptake of the dominant species was calculated as follows:

$\mathrm{S}_{\text {uptake }}=\sum\left(\mathrm{S}_{i} \times m_{i}\right)$,

where $\mathrm{S}_{i}$ represents $\mathrm{S}$ concentration in plant species $i$ and $m_{i}$ represents aboveground biomass of the corresponding species.

\subsection{Statistical analysis}

The Kolmogorov-Smirnov test and Levene's test were executed to determine the normality of data and homogeneity of variances, respectively. The TIN concentration was $\log _{10^{-}}$ transformed for homogeneity. We used three-way ANOVAs to determine the effects of $\mathrm{N}$ addition intensity, $\mathrm{N}$ addition frequency, mowing, and their interactions with the concentrations of soil inorganic S fractions and total S. A Student's $t$ test was performed to estimate the difference in plant biomass and $\mathrm{S}$ uptake between two $\mathrm{N}$ frequencies within each $\mathrm{N}$ addition intensity with or without mowing. Correlation analyses were conducted to estimate the relationships 
Table 1. Effects of $\mathrm{N}$ addition and mowing on soil $\mathrm{pH}$, soil organic carbon (SOC), and total inorganic nitrogen (TIN). Data shown are the mean values, and the values in parentheses are standard errors $(n=10)$, which were previously reported in Wang et al. (2018).

\begin{tabular}{|c|c|c|c|c|c|}
\hline \multirow{2}{*}{\multicolumn{2}{|c|}{$\begin{array}{c}\mathrm{N} \text { intensity } \\
\left(\mathrm{g} \mathrm{N} \mathrm{m}^{-2} \mathrm{yr}^{-1}\right)\end{array}$}} & \multicolumn{2}{|c|}{ Unmown } & \multicolumn{2}{|c|}{ Mown } \\
\hline & & $\mathrm{F} 2$ & F12 & $\mathrm{F} 2$ & F12 \\
\hline \multirow[t]{9}{*}{$\mathrm{pH}$} & 0 & $7.49(0.13) \mathrm{a}$ & $7.34(0.08) \mathrm{a}$ & $7.38(0.12) \mathrm{ab}$ & 7.47 (0.12)ab \\
\hline & 1 & $7.60(0.18) \mathrm{a}$ & $7.34(0.08) \mathrm{a}$ & $7.58(0.13) \mathrm{a}$ & $7.28(0.11) a b$ \\
\hline & 2 & $7.40(0.17) \mathrm{a}$ & $7.51(0.19) \mathrm{a}$ & $7.61(0.18) \mathrm{a}$ & $7.64(0.12) \mathrm{a}$ \\
\hline & 3 & 7.48 (0.17)a & $7.33(0.14) \mathrm{a}$ & $7.36(0.21) a b$ & $7.34(0.14) a b$ \\
\hline & 5 & $6.78(0.17) \mathrm{b}$ & $6.99(0.18) \mathrm{a}$ & 6.97 (0.18)abc & $7.30(0.14) \mathrm{ab}$ \\
\hline & 10 & $6.47(0.19) \mathrm{Bb}$ & $7.08(0.18) \mathrm{Aa}$ & $6.80(0.16) \mathrm{bcd}$ & $7.01(0.17) b$ \\
\hline & 15 & $6.24(0.24) \mathrm{Bb}$ & $7.08(0.18) \mathrm{Aa}$ & $6.42(0.30) \mathrm{cd}$ & $6.48(0.18) c$ \\
\hline & 20 & $5.56(0.16) \mathrm{Bc}$ & $6.22(0.23) \mathrm{Ab}$ & $6.13(0.31) \mathrm{de}$ & $6.08(0.24) c$ \\
\hline & 50 & $5.21(0.26) \mathrm{c}$ & $5.13(0.15) \mathrm{c}$ & $5.54(0.32) \mathrm{e}$ & $5.41(0.29) \mathrm{d}$ \\
\hline \multirow{9}{*}{$\begin{array}{l}\text { TIN } \\
\left(\mathrm{mg} \mathrm{kg}^{-1}\right)\end{array}$} & 0 & $9.30(0.61) \mathrm{c}$ & $10.13(0.72) \mathrm{d}$ & $9.78(0.65) \mathrm{d}$ & $9.20(0.89) \mathrm{c}$ \\
\hline & 1 & $10.29(1.02) \mathrm{c}$ & $10.24(1.00) \mathrm{d}$ & $10.13(0.53) \mathrm{d}$ & $9.74(0.68) \mathrm{c}$ \\
\hline & 2 & $11.09(1.00) \mathrm{c}$ & $9.64(0.62) \mathrm{d}$ & $10.97(0.63) \mathrm{d}$ & $10.88(0.82) \mathrm{c}$ \\
\hline & 3 & $10.19(1.13) \mathrm{c}$ & $10.61(0.87) \mathrm{d}$ & $11.94(0.80) \mathrm{d}$ & $10.75(0.55) \mathrm{c}$ \\
\hline & 5 & $14.62(1.34) \mathrm{c}$ & $13.19(0.88) \mathrm{d}$ & $14.70(1.22) \mathrm{Ad}$ & $10.29(1.00) \mathrm{Bc}$ \\
\hline & 10 & $17.31(3.38) \mathrm{c}$ & $22.51(2.47) \mathrm{c}$ & $18.54(2.92) \mathrm{cd}$ & $17.80(2.31) b c$ \\
\hline & 15 & $30.69(5.46) \mathrm{b}$ & 31.04 (3.77)b & $32.22(4.41) b c$ & $25.84(4.44) \mathrm{b}$ \\
\hline & 20 & 41.03 (5.77)b & 36.48 (4.29)b & $36.46(7.05) \mathrm{b}$ & $28.05(3.58) b$ \\
\hline & 50 & 104.09(10.62)Aa & $74.60(6.22) \mathrm{Ba}$ & 111.94(15.14)Aa & 71.93(10.32)Ba \\
\hline \multirow[t]{9}{*}{$\operatorname{SOC}(\%)$} & 0 & $2.42(0.06) \mathrm{Aa}$ & $2.17(0.05) \mathrm{Bb}$ & $2.60(0.09) \mathrm{Aa}$ & $2.22(0.11) \mathrm{Bab}$ \\
\hline & 1 & $2.45(0.08) \mathrm{Aa}$ & $2.24(0.06) \mathrm{Bb}$ & $2.45(0.09) \mathrm{ab}$ & $2.33(0.15) \mathrm{ab}$ \\
\hline & 2 & $2.17(0.07) b$ & $2.22(0.06) \mathrm{b}$ & 2.36 (0.11)Aabc & $2.07(0.08) \mathrm{Bb}$ \\
\hline & 3 & $2.16(0.07) \mathrm{b}$ & $2.36(0.13) \mathrm{ab}$ & $2.36(0.11) a b c$ & $2.27(0.10) a b$ \\
\hline & 5 & $2.19(0.06) \mathrm{Bb}$ & $2.53(0.09) \mathrm{Aa}$ & $2.27(0.08) b c$ & $2.35(0.08) \mathrm{ab}$ \\
\hline & 10 & $2.26(0.09) \mathrm{ab}$ & $2.39(0.10) \mathrm{ab}$ & $2.25(0.08) b c$ & 2.47 (0.09)a \\
\hline & 15 & $2.12(0.08) b$ & $2.21(0.11) \mathrm{b}$ & $2.14(0.11) b c$ & $2.35(0.10) \mathrm{ab}$ \\
\hline & 20 & $2.43(0.09) \mathrm{a}$ & 2.33(0.08)ab & $2.10(0.09) \mathrm{c}$ & 2.27(0.11)ab \\
\hline & 50 & $2.31(0.05) \mathrm{ab}$ & $2.18(0.10) \mathrm{b}$ & $2.28(0.07) b c$ & $2.36(0.07) \mathrm{ab}$ \\
\hline
\end{tabular}

$\mathrm{F} 2$ and $\mathrm{F} 12$ represent low and high frequencies of $\mathrm{N}$ addition, respectively. Uppercase letters indicate significant differences between means of low and high frequency of $\mathrm{N}$ addition under each $\mathrm{N}$ intensity with or without mowing. Lowercase letters indicate significant differences among means of different $\mathrm{N}$ intensities under each $\mathrm{N}$ frequency with or without mowing.

between soil parameters and concentration of soil S fractions. The proportion of $\mathrm{S}$ fractions relative to total $\mathrm{S}$ was calculated and Duncan's multiple range test was employed to estimate differences among treatments. All the analyses above were conducted using SPSS 18.0 (SPSS Inc., Chicago, IL, USA) and all statistical significance was accepted at $P<0.05$. Moreover, we calculated the response ratio of available $\mathrm{S}$ concentration to mowing as follows:

response ratio $=\frac{S_{\text {mown }}}{S_{\text {unmown }}}$,

where $S_{\text {mown }}$ and $S_{\text {unmown }}$ represent available $S$ concentration in mown and unmown plots, respectively. Weighted logresponse ratio $\left(\log _{e} \mathrm{RR}\right)$ and its $95 \%$ confidence intervals for the effect of mowing were calculated using the metafor package in R software, version 3.5.1 (Viechtbauer, 2010). Confidence intervals not overlapping zero indicated significant mowing effects on available $\mathrm{S}$ concentration.
Structural equation modeling (SEM) was conducted to examine the direct and indirect strengths of $\mathrm{N}$ addition intensities and frequencies on soil inorganic $\mathrm{S}$ fractions through the changes in soil parameters with the AMOS 24.0 program (Amos Development Co., Greene, Maine, USA). Data from all the treatment were pooled for the SEM analysis. An a priori model (Fig. S1a in the Supplement) was constructed by assuming that soil $\mathrm{S}$ fractions could be directly affected by $\mathrm{N}$ addition frequency, intensity, and mowing, or indirectly by altering soil $\mathrm{pH}$, plant biomass return, and organic $\mathrm{S}$ mineralization (see hypotheses in the Introduction). Insignificant pathways and parameters that had no effect on inorganic fractions were excluded from the model sequentially to obtain the final model (Fig. S1b, c). Data were fitted to the model using the maximum likelihood estimation method. We used $\chi^{2}$ test $(P>0.05)$, root-mean-square error of approximation (RMSEA, <0.08), and Akaike information criteria (AIC) to evaluate the adequacy of the model. 


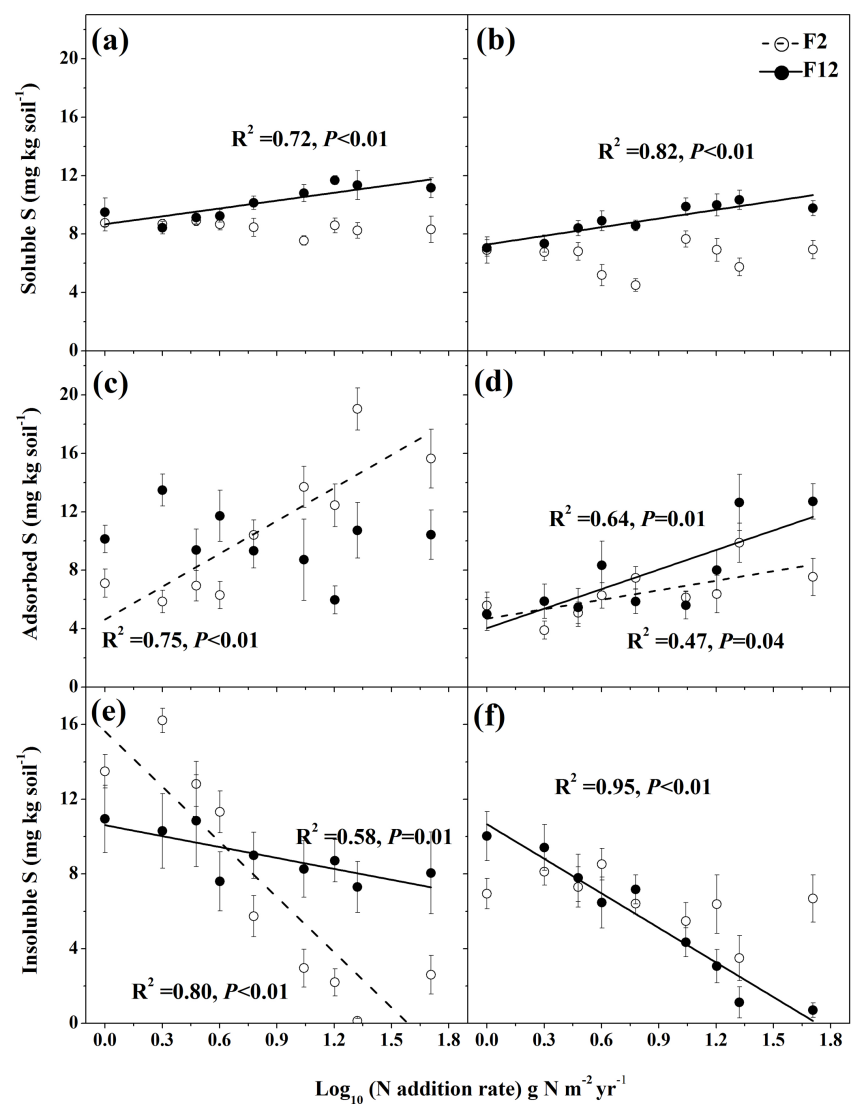

Figure 2. Effects of $\mathrm{N}$ addition intensity and frequency on concentrations of soil-soluble $S(\mathbf{a}, \mathbf{b})$, adsorbed $S(\mathbf{c}, \mathbf{d})$, and insoluble $S$ $(\mathbf{e}, \mathbf{f})$ in unmown $(\mathbf{a}, \mathbf{c}, \mathbf{e})$ ) and mown plots $(\mathbf{b}, \mathbf{d}, \mathbf{f})$. Dashed and solid regression lines represent 2 and $12 \mathrm{~N}$ additions per year, respectively. Error bars indicate standard error.

\section{Results}

\subsection{Effects of $\mathrm{N}$ addition and mowing on soil characteristics}

Soil $\mathrm{pH}$ significantly decreased and the TIN concentration increased along the $\mathrm{N}$ gradient under all treatments of addition frequencies and mowing regimes (Table 1). Soil $\mathrm{pH}$ exhibited a sharper decrease in low $\mathrm{N}$ frequency compared with high $\mathrm{N}$ frequency in unmown plots, especially at $\mathrm{N}$ addition intensities of 10 and $15 \mathrm{~g} \mathrm{~N} \mathrm{~m}^{-2} \mathrm{yr}^{-1}$. Low frequency of $\mathrm{N}$ addition increased TIN concentration in both unmown and mown plots at high $\mathrm{N}$ levels $\left(P<0.05\right.$ at $\left.50 \mathrm{~g} \mathrm{~N} \mathrm{~m}^{-2} \mathrm{yr}^{-1}\right)$. The SOC concentration decreased along the $\mathrm{N}$ gradient only under low $\mathrm{N}$ frequency in mown plots.

\subsection{Effects of $\mathbf{N}$ addition and mowing on soil inorganic $\mathrm{S}$ fractions}

\subsubsection{Soil-soluble $S$}

Mowing significantly decreased soil-soluble $\mathrm{S}$ concentration by up to $47 \%$ among all $\mathrm{N}$ addition frequencies and intensities (Fig. 2a, b; Table 2). The high frequency of $\mathrm{N}$ addition significantly increased soluble S concentration by up to $90 \%$ in both unmown and mown plots, resulting in a significant $M \times F$ effect (Fig. 2a, b; Table 2). With a high frequency of $\mathrm{N}$ addition, $\mathrm{N}$ addition intensity increased soluble $\mathrm{S}$ for both unmown (Fig. 2a, $P=0.004$ ) and mown plots (Fig. 2b, $P=0.001$ ), causing a significant $F \times N$ effect (Table 2).

\subsubsection{Soil adsorbed S}

Soil adsorbed S concentration was significantly affected by mowing treatments and intensity of $\mathrm{N}$ addition (Table 2). Mowing significantly decreased soil adsorbed $\mathrm{S}$ concentration at low $\mathrm{N}$ addition frequency (Fig. 2c, d; Table 2). There was no effect of $\mathrm{N}$ addition frequency on adsorbed $\mathrm{S}$ (Table 2). Compared to the control plot, $\mathrm{N}$ addition intensity increased soil adsorbed $\mathrm{S}$ concentration at low frequency of $\mathrm{N}$ addition in unmown plots (Fig. $2 \mathrm{c}, P<0.01$ ) and at both low and high frequencies of $\mathrm{N}$ addition (Fig. 2d, $P=0.04$ and 0.01 , respectively) in mown plots, causing significant $M \times F$ and $F \times N$ effects (Table 2).

\subsubsection{Soil-insoluble $S$}

Mowing decreased soil-insoluble $\mathrm{S}$ concentration by up to $91 \%$ across $\mathrm{N}$ treatments (Fig. 2e, f). There was no significant effect of $\mathrm{N}$ addition frequency on soil-insoluble $\mathrm{S}$ (Table 2). Intensity of $\mathrm{N}$ addition decreased soil-insoluble $\mathrm{S}$ concentration at both low and high $\mathrm{N}$ frequency for unmown plots (Fig. 2e; Table 2, $P=0.01$ and $<0.01$, respectively) but only at high $\mathrm{N}$ addition frequencies for mown plots (Fig. 2f, $P<0.01$ ), resulting in significant $M \times F$ and $M \times F \times N$ effects on soil-insoluble $\mathrm{S}$ concentration (Table 2).

\subsection{Effects of $\mathbf{N}$ addition and mowing on soil-available S}

Mowing significantly decreased soil-available S concentration by up to $43 \%$ and $40 \%$ across $\mathrm{N}$ intensity at low and high $\mathrm{N}$ addition frequencies, respectively (Fig. 3a, b; Table 2). For mown plots, high frequency of $\mathrm{N}$ addition significantly increased soil-available $\mathrm{S}$ concentration by up to $57 \%$ compared with low $\mathrm{N}$ frequency across $\mathrm{N}$ addition intensity (Fig. 3b; Table 2). The high intensity of $\mathrm{N}$ addition increased soil-available $\mathrm{S}$ concentration at the lower frequency of $\mathrm{N}$ addition for unmown plots from 15.9 to $24.0 \mathrm{mg}$ per kilogram soil (Fig. 3a, $P<0.01$ ), and at both low (from 10.7 to $15.6 \mathrm{mg}$ per kilogram soil, $P=0.01$ ) and high (from 12.0 to $23.0 \mathrm{mg}$ per kilogram soil, $P<0.01$ ) frequencies of $\mathrm{N}$ ad- 
Table 2. Results of three-way ANOVAs ( $F$ value) for the effects of mowing $(M), \mathrm{N}$ addition frequency $(F)$, and intensity $(N)$ on soil sulfur (S) fractions and total $\mathrm{S}$ concentration.

\begin{tabular}{llllllll}
\hline & SS & AdS & AvS & InS & TIS & OS & TS \\
\hline$M$ & $74.46^{* *}$ & $60.40^{* *}$ & $145.25^{* *}$ & $28.32^{* *}$ & $449.97^{* *}$ & 3.43 & 2.91 \\
$F$ & $120.82^{* *}$ & 0.23 & $31.59^{* *}$ & 0.35 & $57.77^{* *}$ & 0.17 & 0.08 \\
$N$ & $3.95^{* *}$ & $11.36^{* *}$ & $16.64^{* *}$ & $21.83^{* *}$ & $5.94^{* *}$ & 1.45 & 1.48 \\
$M \times F$ & $4.80^{*}$ & $5.98^{*}$ & $12.59^{* *}$ & $9.62^{* *}$ & 0.35 & 0 & 0 \\
$M \times N$ & 1.22 & 0.84 & 0.66 & 1.67 & $3.91^{* *}$ & 0.39 & 0.80 \\
$F \times N$ & $5.05^{* *}$ & $4.83^{* *}$ & $2.53^{*}$ & $2.55^{* *}$ & 0.47 & 0.81 & 0.39 \\
$M \times F \times N$ & 1.45 & $6.65^{* *}$ & $6.34^{* *}$ & $8.37^{* *}$ & 1.05 & 1.38 & 1.42 \\
\hline
\end{tabular}

Note: SS represents soluble S, AdS represents adsorbed S, AvS represents available S, InS represents insoluble S, TIS represents soil total inorganic S, OS represents organic S, and TS represents soil total S. The symbols * and ** represent significance levels at 0.05 and 0.01 , respectively.

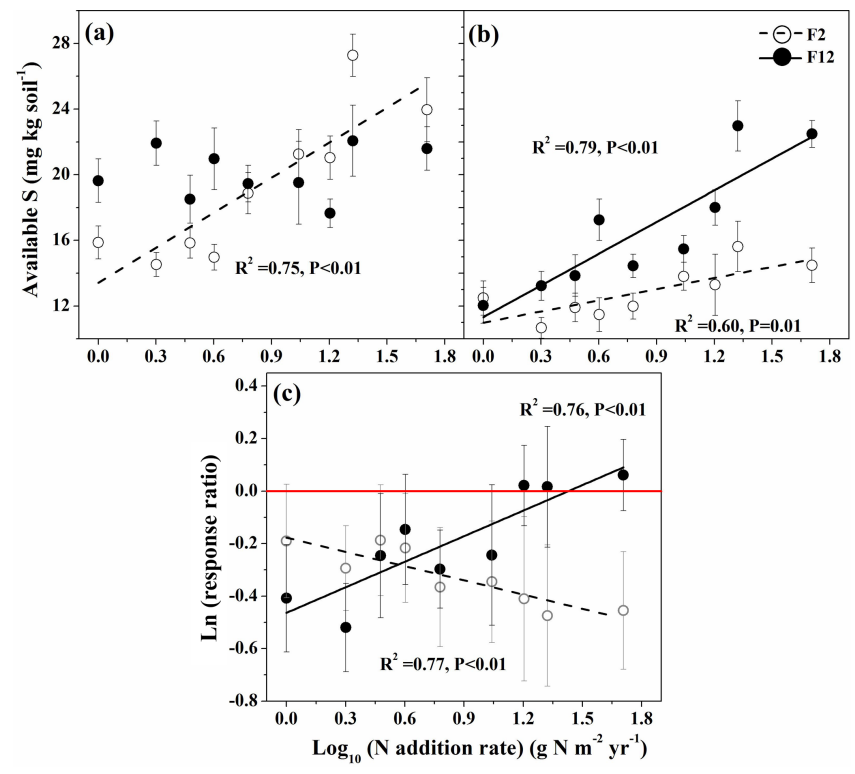

Figure 3. Effects of $\mathrm{N}$ addition intensity and frequency on soilavailable $\mathrm{S}$ concentration in unmown (a) and mown plots (b), and response ratio of soil-available $\mathrm{S}$ to mowing along the $\mathrm{N}$ addition rate (c). Dashed and solid regression lines represent 2 and $12 \mathrm{~N}$ additions per year, respectively. Error bars indicate standard errors in (a) and (b), and $95 \%$ confidence intervals in (c).

dition for mown plots (Fig. 3b). This resulted in significant interactive effects of $M \times F, F \times N$, and $M \times F \times N$ on soilavailable $\mathrm{S}$ (Table 2).

Nitrogen addition intensity enhanced the negative effect of mowing on soil-available $\mathrm{S}$ concentration at low $\mathrm{N}$ frequency (Fig. 3c, $P<0.01$ ). However, negative mowing effect on available $\mathrm{S}$ concentration decreased along the increasing $\mathrm{N}$ addition intensity and even turned into positive at 15, 20, and $50 \mathrm{~g} \mathrm{~N} \mathrm{~m}^{-2} \mathrm{yr}^{-1}$ at high frequency of $\mathrm{N}$ addition (Fig. 3c, $P<0.01)$. The proportion of available $\mathrm{S}$ relative to total $\mathrm{S}$ increased with increasing $\mathrm{N}$ intensity at low $\mathrm{N}$ frequency for unmown plots (Fig. S2a) and at both low and high $\mathrm{N}$ frequencies for mown plots (Fig. S2c, d).

\subsection{Effects of $\mathrm{N}$ addition and mowing on soil total inorganic $S$, total $S$, plant biomass, and plant $S$ uptake}

Mowing significantly decreased total inorganic $\mathrm{S}$ at both low and high frequencies of $\mathrm{N}$ addition by up to $38 \%$ (Fig. 4a, b). The high frequency of $\mathrm{N}$ addition significantly increased soil total inorganic $\mathrm{S}$ concentration by as much as $15 \%$ (unmown plots) and $26 \%$ (mown plots) compared with low $\mathrm{N}$ frequency (Fig. 4a, b). Soil total inorganic $\mathrm{S}$ concentration decreased with increasing $\mathrm{N}$ intensity (except for 20 and $50 \mathrm{~g} \mathrm{~N} \mathrm{~m}^{-2} \mathrm{yr}^{-1}$ ) for both $\mathrm{N}$ frequencies in unmown plots, while it showed no response in mown plots. Soil organic $S$ and total $\mathrm{S}$ concentrations were not affected by the intensity of $\mathrm{N}$ addition, frequency of $\mathrm{N}$ addition, and mowing treatment as suggested by three-way ANOVAs (Table 2). However, the mean values of soil organic and total $\mathrm{S}$ concentration tended to decrease with increasing $\mathrm{N}$ addition intensity as indicated by its linear correlation with $\mathrm{N}$ addition intensity at both low and high $\mathrm{N}$ addition frequencies in mown plots (Fig. 4d, f). Mowing significantly decreased the proportion of total inorganic $\mathrm{S}$ relative to total $\mathrm{S}$ and increased organic $S$ proportion (Figs. S2a vs. 2c and Figs. S2b vs. 2d).

The high intensity of $\mathrm{N}$ addition increased aboveground biomass regardless of $\mathrm{N}$ addition frequency and mowing management (Fig. S3). The low frequency of $\mathrm{N}$ addition increased aboveground biomass at 2 and $15 \mathrm{~g} \mathrm{~N} \mathrm{~m}^{-2} \mathrm{yr}^{-1}$ compared with high frequency of $\mathrm{N}$ addition in unmown plots. Sulfur uptake of Leymus chinensis and Stipa grandis showed no response to mowing management in plots without $\mathrm{N}$ addition, but it increased with mowing under both frequencies of $\mathrm{N}$ addition. Low frequency of $\mathrm{N}$ addition increased $\mathrm{S}$ uptake of the dominant species at $15 \mathrm{~g} \mathrm{~N} \mathrm{~m}^{-2} \mathrm{yr}^{-1}$ in both mown and unmown plots (Fig. 5). Nitrogen addition intensity increased plant S concentration of two dominant species (Fig. S4) and relative biomass proportion of Stipa grandis (Fig. S5). 


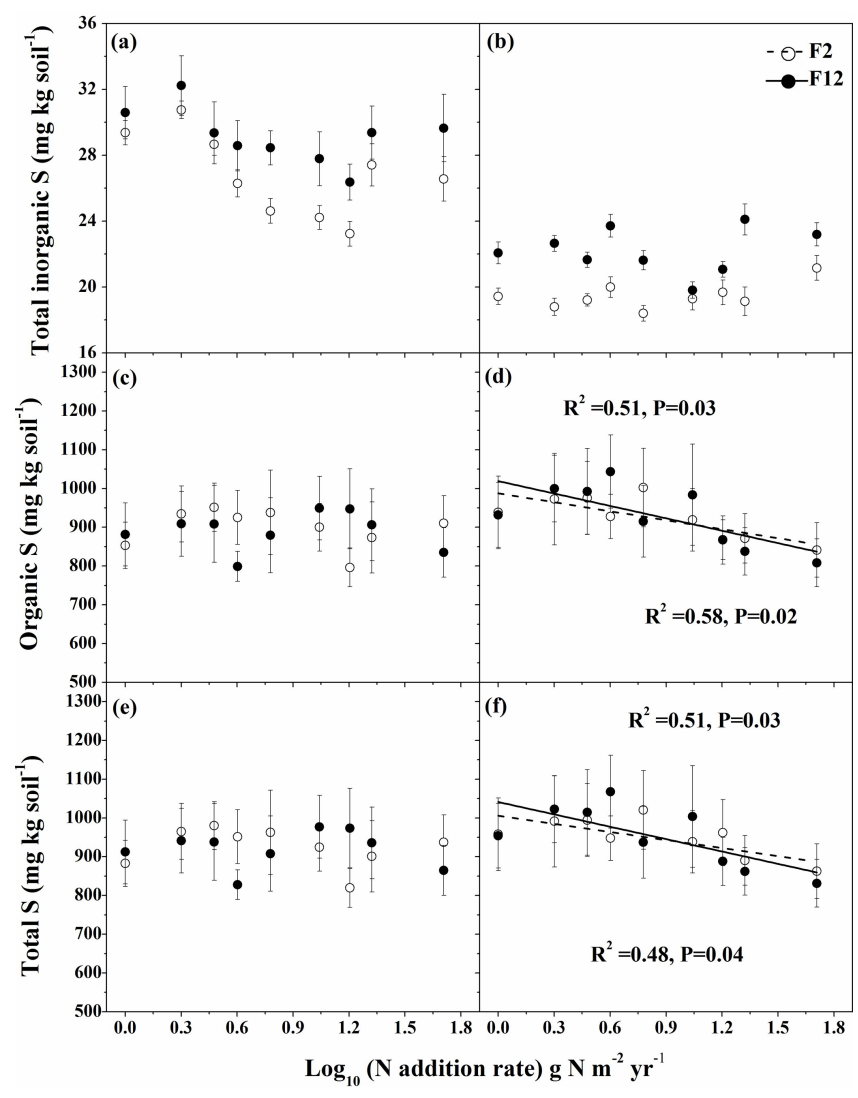

Figure 4. Effects of $\mathrm{N}$ addition intensity and frequency on concentrations of soil total inorganic $S(\mathbf{a}, \mathbf{b})$, organic $S(\mathbf{c}, \mathbf{d})$, and total $\mathrm{S}(\mathbf{e}, \mathbf{f})$ in unmown $(\mathbf{a}, \mathbf{c}, \mathbf{e})$ and mown $(\mathbf{b}, \mathbf{d}, \mathbf{f})$ plots. Dashed and solid regression lines correspond to 2 and $12 \mathrm{~N}$ additions per year, respectively. Error bars indicate standard errors.

\subsection{Relationships between soil characteristics and $\mathrm{S}$ fractions}

Soil $\mathrm{pH}$ was negatively correlated with adsorbed $\mathrm{S}$ and available $\mathrm{S}$ concentrations under both low (Fig. 6a) and high frequencies of $\mathrm{N}$ addition (Fig. 6b) (all $P<0.01$ ). However, insoluble $\mathrm{S}$ was positively correlated with $\mathrm{pH}$ under both $\mathrm{N}$ frequencies. Soil TIN concentration was positively correlated with adsorbed $\mathrm{S}$ and available $\mathrm{S}$ but negatively correlated with insoluble $\mathrm{S}$ concentration under both low and high frequencies of $\mathrm{N}$ addition. Soil organic carbon was positively correlated with soluble $\mathrm{S}$ under both $\mathrm{N}$ frequencies. Insoluble $\mathrm{S}$ was negatively correlated with adsorbed and available $\mathrm{S}$ under both $\mathrm{N}$ frequencies (all $P<0.01$, Fig. 6a, b). Organic $\mathrm{S}$ concentration was negatively correlated with adsorbed $\mathrm{S}$ and available $\mathrm{S}$ at high frequency of $\mathrm{N}$ addition $(P<0.01$, Fig. 6b).

Results of SEM showed that $\mathrm{N}$ addition intensity affected soil inorganic $\mathrm{S}$ fractions through altering soil $\mathrm{pH}$, plant biomass, and SOC concentration (Fig. 7a, b). Plant biomass, representing plant $\mathrm{S}$ uptake, showed a negative effect on ad-

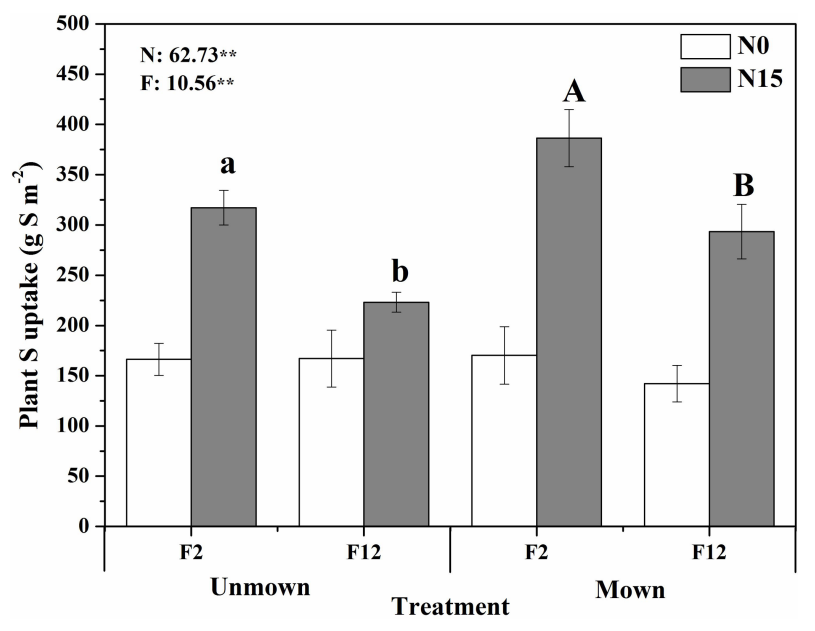

Figure 5. Effect of $\mathrm{N}$ addition intensity and frequency on plant $\mathrm{S}$ uptake by the dominant species of Leymus chinensis and Stipa grandis, with and without mowing (only plant samples in 0 and $15 \mathrm{~g} \mathrm{~N} \mathrm{~m}^{-2} \mathrm{yr}^{-1}$ were measured). F2 and F12 indicate low and high frequencies of $\mathrm{N}$ addition, respectively. Error bars indicate the standard error. Effects of $\mathrm{N}$ addition intensity $(N)$ and frequency $(F)$ from three-way ANOVAs were labeled with ${ }^{* *}$ and represent a significance level of 0.01. Different letters above the bars represent the significant difference among means for the $\mathrm{N}$ addition frequency (F2 vs. F12) at $15 \mathrm{~g} \mathrm{~N} \mathrm{~m}^{-2} \mathrm{yr}^{-1}$ (N15) without (lowercase letters) and with mowing (capital letters) separately. No significant difference was detected (not labeled) between the two $\mathrm{N}$ frequencies at $0 \mathrm{~g} \mathrm{~N} \mathrm{~m}^{-2} \mathrm{yr}^{-1}$ for both mown and unmown treatments (N0).

sorbed S concentration. With increasing intensity of $\mathrm{N}$ addition, higher plant biomass increased soil organic carbon, which elevated soil-soluble $\mathrm{S}$ concentration (Fig. 7b). The frequency of $\mathrm{N}$ addition directly and positively affected soilsoluble S (standardized total effect size: 0.26 ) but indirectly influenced adsorbed S (effect size: 0.07) and inorganic S (effect size: 0.05 ) concentrations by changing soil $\mathrm{pH}$ (Fig. 7c). Consistent with the results of simple regressions, soil $\mathrm{pH}$ had a negative effect on soil adsorbed $S$, which was positive for soil-insoluble S. Mowing decreased soluble S, adsorbed S, and insoluble $\mathrm{S}$ concentrations (Fig. 7d).

\section{Discussion}

\subsection{Positive effects of $\mathrm{N}$ addition intensity on soil-available $S$ resulted from higher abiotic dissolution, adsorption, and potential organic $S$ mineralization}

Consistent with the first hypothesis, increasing $\mathrm{N}$ addition intensity enhanced soil-available $\mathrm{S}$ fractions, especially adsorbed S concentrations. In this study, higher adsorbed S under $\mathrm{N}$ addition was due to the fact that the level of sulfate adsorption increased with the decrease in soil pH (Fig. 7b), which was in line with Nodvin et al. (1986). Adsorption of 

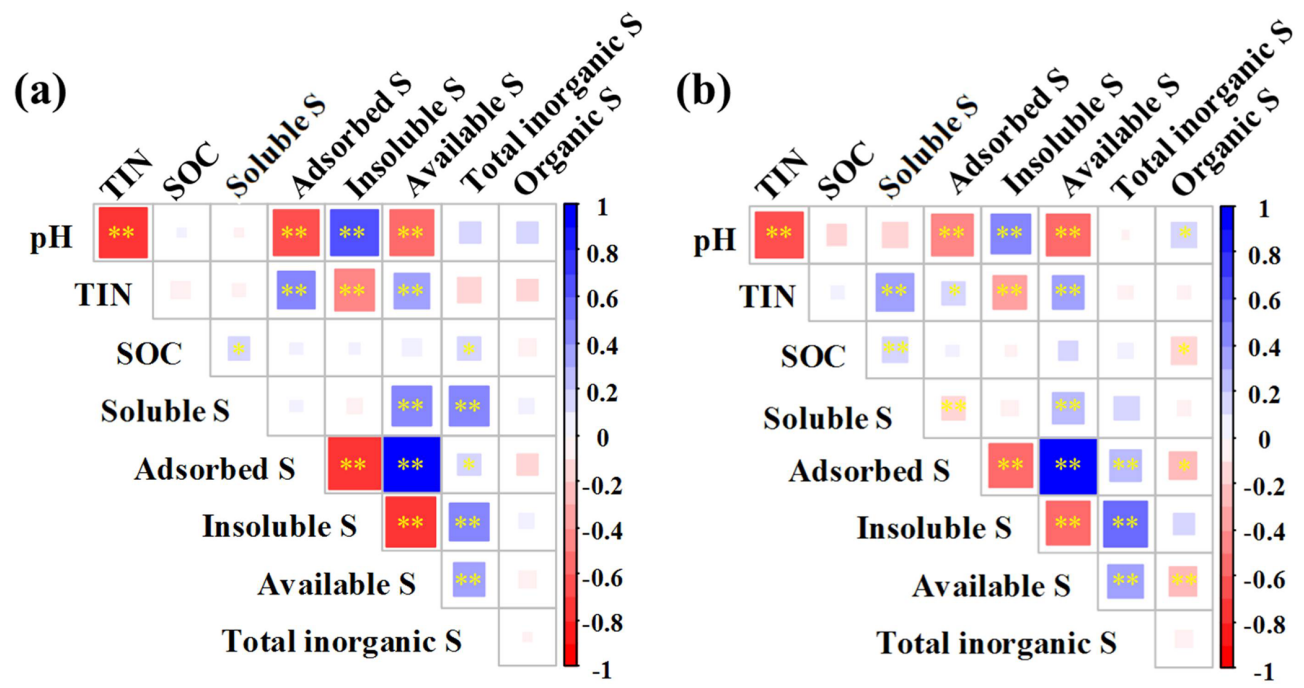

Figure 6. Correlations between soil parameters and $\mathrm{S}$ fractions with low (a) and high (b) frequencies of $\mathrm{N}$ addition across differing $\mathrm{N}$ addition intensities and mowing treatments. The color change from blue to red indicates correlations from positive to negative as exhibited in bars at right side of each panel. The symbols $*$ and ${ }^{* *}$ represent significance levels of 0.05 and 0.01 , respectively.

$\mathrm{SO}_{4}^{2-}$ is $\mathrm{pH}$ dependent as anionic groups from SOM compete with $\mathrm{SO}_{4}^{2-}$ for adsorption sites on iron and aluminum hydroxides (Johnson and Todd, 1983). Under acidic conditions, soil matrix can provide adsorption sites with positive charges to attract the negatively charged $\mathrm{SO}_{4}^{2-}$ (Tabatabai, 2005). Therefore, lower soil $\mathrm{pH}$ contributed to higher adsorbed $\mathrm{S}$ concentration via enhancing adsorption strength and increasing electrostatic potential of the adsorption sites under higher intensities of $\mathrm{N}$ addition (Scherer et al., 2012). However, unaffected adsorbed $\mathrm{S}$ in unmown plots could be possibly due to the fact that soil $\mathrm{pH}$ tended to be higher at high $\mathrm{N}$ frequency compared with low $\mathrm{N}$ frequency at the same $\mathrm{N}$ addition level (significant at 10,15, and $20 \mathrm{~g} \mathrm{~N} \mathrm{~m}^{-2} \mathrm{yr}^{-1}$; see Table 1). Moreover, soil $\mathrm{pH}$ decreased at a much lower rate along with increasing $\mathrm{N}$ addition intensity (significant decreases only detected at 20 and $50 \mathrm{~g} \mathrm{~N} \mathrm{~m}^{-2} \mathrm{yr}^{-1}$ ) under high $\mathrm{N}$ addition frequency compared with low $\mathrm{N}$ addition frequency. This resulted in weaker $\mathrm{S}$ adsorption strength, less $\mathrm{SO}_{4}^{2-}$ release from insoluble $\mathrm{S}$ dissolution, and consequently unchanged adsorbed $\mathrm{S}$ concentration with increasing $\mathrm{N}$ intensity at high $\mathrm{N}$ frequency.

Increasing $\mathrm{N}$ addition intensity enhanced soil-available $\mathrm{S}$ fractions partially due to the dissolution of soil-insoluble $S$ as suggested by the negative correlation between the two $\mathrm{S}$ fractions in our study (Fig. 6). Without $\mathrm{N}$ deposition, free sulfate in soil could precipitate as calcium-, magnesium-, or sodium sulfate and co-crystallize or co-precipitate with $\mathrm{CaCO}_{3}$ (Tisdale et al., 1993), especially in calcareous soil rich in exchangeable $\mathrm{Ca}^{2+}, \mathrm{Mg}^{2+}$, and $\mathrm{Na}^{+}$(Wang et al., 2018). Soil acidification induced by $\mathrm{N}$ addition can reverse the precipitation process by dissolving $\mathrm{CaCO}_{3}$-sulfate complexes (Chen et al., 1997; Zhang et al., 2016). Therefore, insoluble S dissolution sequentially enhanced $\mathrm{SO}_{4}^{2-}$ mobility due to soil acid- ification under excessive $\mathrm{N}$ input. This postulation was further confirmed by the positive relationships of soil $\mathrm{pH}$ and insoluble $\mathrm{S}$ at both $\mathrm{N}$ frequencies (Fig. 6a, b). For the insoluble $\mathrm{S}$ fraction, cautions should be paid to the fact that a small part of organic $\mathrm{S}$ might be oxidized into inorganic $\mathrm{S}$ during $\mathrm{H}_{2} \mathrm{O}_{2}(1 \mathrm{~mL})$ digestion (Williams and Steinbergs, 1959). At low $\mathrm{N}$ frequency of $\mathrm{N}$ addition, the non-significant effect of $\mathrm{N}$ intensity on soluble $\mathrm{S}$ concentration could probably attribute to the balance between $\mathrm{S}$ adsorption and dissolution processes under soil acidification thus keeping the concentration of soluble $\mathrm{S}$ stable. Soluble $\mathrm{S}$ is the most active and mobile $S$ fraction in topsoil for it can be easily utilized by plants and leached along with soil pore water (Tabatabai, 2005). The increase in soluble $\mathrm{S}$ with a high frequency of $\mathrm{N}$ addition indicates that $\mathrm{N}$ deposition might increase the risk of S losses via leaching and/or surface runoff.

Our results demonstrate that $\mathrm{N}$ input increased soilavailable $\mathrm{S}$ potentially by increasing organic $\mathrm{S}$ mineralization in mown plots as indicated by the decreased organic $\mathrm{S}$ concentration (Fig. 4d). This was consistent with previous observations that $\mathrm{N}$ addition enhanced mineralization of organic $\mathrm{S}$ to increase $\mathrm{S}$ availability by elevating microbial activity (Ghani et al., 1992). Soil N availability has considerable impacts on the mineralization of organic S (NiknahadGharmakher et al., 2009). The increase in soil TIN concentration following $\mathrm{N}$ input possibly accelerated organic $\mathrm{S}$ mineralization in this study. Changes in SOC concentration also contributed to the increase in soluble S (Fig. 7a) as biological mineralization of C-bonded $\mathrm{S}$ was positively related to SOC concentration (Niknahad-Gharmakher et al., 2009). Moreover, decrease in soil $\mathrm{pH}$ and higher plant $\mathrm{S}$ uptake under $\mathrm{N}$ input (Fig. 5) could promote biochemical mineralization of organic $\mathrm{S}$ via the enhancement of arylsulfatase secretion by 


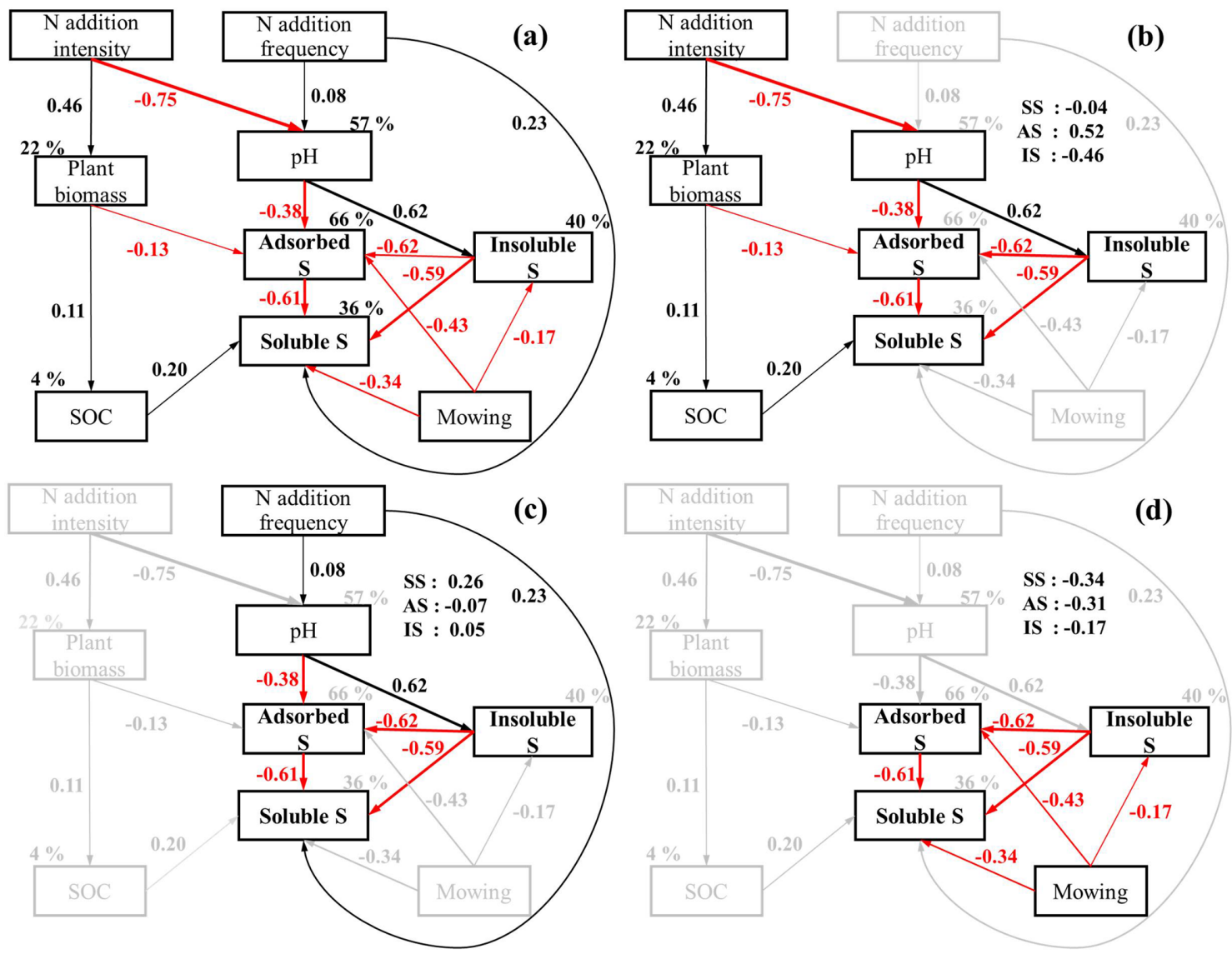

Figure 7. Structural equation modeling (SEM) illustrating the pathways of effects of $\mathrm{N}$ addition intensity, frequency, and mowing on soil parameters and inorganic S fractions. Panel (a) shows the original model, panel (b) depicts the pathways related to effects of $\mathrm{N}$ intensity, panel (c) depicts the pathways related to effects of $\mathrm{N}$ frequency, and panel (d) depicts the depicts the pathways related to effects of mowing. Arrows indicate significantly positive (black) and negative (red) effects with the effect size proportional to arrow width. Numbers adjacent to arrows are standardized path coefficients, and percentages next to the endogenous variables indicate the variance explained by the model $\left(R^{2}\right)$. The numbers in the top-right corner denote the standardized total effects of $\mathrm{N}$ intensity, frequency, and mowing on soluble $\mathrm{S}$ (SS), adsorbed S (AS), and insoluble S (IS), respectively. The final SEM fitted the data well as suggested by the fitting parameters $\left(\chi^{2}=21.06\right.$, $\mathrm{d} f=23, P=0.58$, RMSEA $=0.000$, and $\mathrm{AIC}=85.06)$.

soil microorganisms (McGill and Cole, 1981). This was further confirmed by Niknahad-Gharmakher et al. (2009), who reported the upregulation of soil organic $\mathrm{S}$ mineralization by the decrease in soil $\mathrm{pH}$. Elevation of soil $\mathrm{S}$ availability via the two pathways of insoluble $\mathrm{S}$ dissolution and organic $\mathrm{S}$ mineralization implies that $\mathrm{N}$ deposition would substantially promote transportation of soil $\mathrm{S}$ into plant biomass in the semiarid grassland. This finding is relevant to understand the fates of $\mathrm{S}$ under ecosystem $\mathrm{N}$ enrichment with the presence of other disturbances such as mowing and livestock grazing of grasslands.

\subsection{Effects of $\mathrm{N}$ addition frequency on soil inorganic $\mathrm{S}$ fractions}

Partially contrary to our second hypothesis, low frequency of $\mathrm{N}$ addition decreased soluble $\mathrm{S}$, adsorbed $\mathrm{S}$, available $\mathrm{S}$, and total inorganic S concentrations compared with highfrequency addition. A change in soil-available $\mathrm{S}$ concentration was mainly determined by the input from dissolution of insoluble S and output to plant uptake and leaching. A sharper decrease in soil $\mathrm{pH}$ with low $\mathrm{N}$ frequency relative to high $\mathrm{N}$ frequency would result in higher soil-available $\mathrm{S}$ concentration via the enhancement of insoluble $\mathrm{S}$ dissolution. On the contrary, lower available $\mathrm{S}$ concentration was found under low $\mathrm{N}$ frequency compared with high $\mathrm{N}$ frequency (Fig. 3), which could be possibly driven by higher plant S uptake (Fig. 5), surpassing the amount of S dissolution. Leaching loss of $\mathrm{SO}_{4}^{2-}$ was evident with infrequent and extreme rainfall pulses in sandy soils (Eriksen and Askegaard, 2000). Therefore, another potential explanation could be that largepulse water input at low $\mathrm{N}$ frequency resulted in higher leaching loss of available $\mathrm{S}$ than the high $\mathrm{N}$ frequency of adding a small amount of water each time. The results in the con- 
trol plots supported this explanation, with lower concentrations of adsorbed $\mathrm{S}$, available $\mathrm{S}$, and total inorganic $\mathrm{S}$ under low $\mathrm{N}$ frequency compared with high-frequency (especially in unmown plots). With the increasing $\mathrm{N}$ intensity, leaching loss of available $\mathrm{S}$ was exacerbated due to enhanced insoluble $\mathrm{S}$ dissolution (Fig. 2e, f). Compared with high $\mathrm{N}$ frequency, organic $\mathrm{S}$ mineralization did not contribute to lower total inorganic $\mathrm{S}$ and available $\mathrm{S}$ concentrations at low $\mathrm{N}$ frequency for the same $\mathrm{N}$ intensity as no difference was detected for organic $\mathrm{S}$ concentration between the two $\mathrm{N}$ frequencies. These results suggest that using low frequency of $\mathrm{N}$ addition to mimic $\mathrm{N}$ deposition may overestimate insoluble $\mathrm{S}$ dissolution (especially in unmown plots) and plant $S$ uptake in temperate grasslands. However, some of the $\mathrm{S}$ fractions responded differently to both $\mathrm{N}$ intensity and frequency with or without mowing treatment, suggesting that the effects of $\mathrm{N}$ addition strongly depended on mowing.

\subsection{Mowing effect and its interaction with $\mathrm{N}$ addition}

Mowing decreased inorganic $\mathrm{S}$ fractions in all treatments, which supports our third hypothesis. Mowing could alter plant community composition (Lü et al., 2012) and ecosystem nutrient cycling (Koncz et al., 2015). Decreased soil nutrient availability was found with mowing in a similar grassland ecosystem resulting from reduced plant residue return (Lü et al., 2012). Similarly, mowing resulted in significant decreases in inorganic $\mathrm{S}$ fractions and the proportion of total inorganic S relative to soil total S (Figs. 4a, b, S2). In contrast, relative organic $\mathrm{S}$ proportion increased with mowing treatment (Fig. S2), which indicates that mowing management removes soil S out of the ecosystem and has a larger impact on inorganic $\mathrm{S}$ transformation than on the organic $\mathrm{S}$ mineralization (Fig. 4a, b vs. Fig. 4c, d). This is contrary to the findings of Li et al. (2001), which suggested that over $70 \%$ of $\mathrm{S}$ removal by harvests was derived from organic $\mathrm{S}$ mineralization in an agroecosystem. The difference could probably be attributed to the relatively lower intensity of plant $\mathrm{S}$ uptake and fertility of soil of the grassland ecosystem than the cropland.

The negative mowing effect on the soil-available $S$ was suggested to be exacerbated due to enhanced plant $S$ uptake coincident with higher plant biomass (Jackson, 2000). We found that combined mowing and $\mathrm{N}$ addition treatments tended to increase S uptake of the dominant species (Fig. 5). This was probably due to higher S concentration in Stipa grandis (Fig. S4) and increases in its biomass proportion after mowing (Fig. S5). However, the exacerbation of the negative mowing effect on available $\mathrm{S}$ was only detected at low frequency of $\mathrm{N}$ addition in this study, and high $\mathrm{N}$ frequency alleviated the negative mowing effect and even turned it into a positive effect $\left(>15 \mathrm{~g} \mathrm{~N} \mathrm{~m}^{-2} \mathrm{yr}^{-1}\right)$ with the increasing $\mathrm{N}$ addition intensity (Fig. 3c). The discrepancy might be recognized as the tradeoff between the available $S$ output and input processes, which are regulated by differential responses of soil $\mathrm{pH}$, plant biomass, and $\mathrm{S}$ uptake in the two $\mathrm{N}$ addition frequencies. Therefore, it was reasonable to detect the decrease in soil total $\mathrm{S}$ but the increase in soluble $\mathrm{S}$ and adsorbed $\mathrm{S}$ concentrations under $\mathrm{N}$ addition with mowing. Our results suggest that the increase in $\mathrm{S}$ removal from the grassland ecosystem could temporally stimulate available $\mathrm{S}$ formation via abiotic dissolution of insoluble $S$ and mineralization of organic S. In the long term, however, $\mathrm{N}$ enrichment together with continuous mowing would cause depletion of the $\mathrm{S}$ pool.

\section{Conclusions}

Increasing the intensity of $\mathrm{N}$ input enhanced soil-available $\mathrm{S}$ fractions by affecting soil $\mathrm{pH}$, plant $\mathrm{S}$ uptake, SOC concentration, and insoluble $\mathrm{S}$ concentration. Dissolution of insoluble $S$ and mineralization of organic $S$ contributed to the increases in soil $\mathrm{S}$ availability. Mowing significantly decreased soil inorganic $\mathrm{S}$ fractions by reducing $\mathrm{S}$ replenishment via plant residue return, and such an effect was exacerbated with increasing intensity of $\mathrm{N}$ addition by enhancing plant $\mathrm{S}$ uptake. Frequency of $\mathrm{N}$ addition also interacted with mowing to decrease soil adsorbed and available $\mathrm{S}$ with a higher response ratio with the low frequency of $\mathrm{N}$ addition. Our results indicated that simulating $\mathrm{N}$ deposition using large and infrequent pulses of $\mathrm{N}$ could overestimate changes in adsorbed $\mathrm{S}$, and available $\mathrm{S}$ under unmown conditions, but underestimate responses of soluble $S$, adsorbed $S$ and available $S$ concentrations under mown conditions. Mowing could regulate the effects of $\mathrm{N}$ addition intensity and frequency on soil $\mathrm{S}$ dynamics in semiarid grassland ecosystems. Our results provide insights for sustainable grassland management from a perspective of S cycling.

Data availability. The datasets used and/or analyzed in the present study are available from the corresponding author on reasonable request.

Supplement. The supplement related to this article is available online at: https://doi.org/10.5194/bg-16-2891-2019-supplement.

Author contributions. $\mathrm{XH}$ and $\mathrm{YJ}$ designed the study. YZ and JY set up the field experiment and applied fertilizer every year. HL, RW, and PH performed samplings of soils and plants. TL, HL, and ZW completed laboratory analyses. RW and X-T L contributed to the interpretation and discussion of the results. TL prepared the manuscript with suggestions from all the co-authors.

Competing interests. The authors declare that they have no conflict of interest. 
Acknowledgements. The authors would like to thank the Inner Mongolia Grassland Ecosystem Research Station for the great assistance during the sampling and in situ measurements. We are grateful to the two referees for their helpful and constructive comments on the previous version of this paper.

Financial support. This research has been supported by the National Natural Science Foundation of China (grant nos. 31870441, 31770525, and 31430016) and the National Key Research and Development Program of China (grant no. 2016YFC0500707).

Review statement. This paper was edited by Nobuhito Ohte and reviewed by two anonymous referees.

\section{References}

Aneja, V. P., Roelle, P. A., Murray, G. C., Southerland, J., Erisman, J. W., Fowler, D., Asman, W. A. H., and Patni, N.: Atmospheric nitrogen compounds II: emissions, transport, transformation, deposition and assessment, Atmos. Environ., 35, 19031911, https://doi.org/10.1016/S1352-2310(00)00543-4, 2001.

Barrow, N. J.: A comparison of the mineralization of nitrogen and of sulphur from decomposing organic materials, Aust. J. Agr. Res., 11, 960-969, https://doi.org/10.1071/AR9600960, 1960.

Barton, L., Wan, G. G. Y., Buck, R. P., and Colmer, T. D.: Does N fertiliser regime influence $\mathrm{N}$ leaching and quality of differentaged turfgrass (Pennisetum clandestinum) stands?, Plant Soil, 316, 81-96, https://doi.org/10.1007/s11104-008-9761-7, 2008.

Bilbrough, C. J. and Caldwell, M. M.: Exploitation of springtime ephemeral $\mathrm{N}$ pulses by six great basin plant species, Ecology, 78, 231-243, https://doi.org/10.2307/2265992, 1997.

Blum, S. C., Lehmann, J., Solomon, D., Caires, E. F., and Alleoni, L. R. F.: Sulfur forms in organic substrates affecting $S$ mineralization in soil, Geoderma, 200, 156-164, https://doi.org/10.1016/j.geoderma.2013.02.003, 2013.

Bobbink, R., Hicks, K., Galloway, J., Spranger, T., Alkemade, R., Ashmore, M., Bustamante, M., Cinderby, S., Davidson, E., Dentener, F., Emmett, B., Erisman, J. W., Fenn, M., Gilliam, F., Nordin, A., Pardo, L., and De Vries, W.: Global assessment of nitrogen deposition effects on terrestrial plant diversity: a synthesis, Ecol. Appl., 20, 30-59, https://doi.org/10.1890/08-1140.1, 2010.

Bremer, D. J. and Ham, J. M.: Measurement and modeling of soil $\mathrm{CO}_{2}$ flux in a temperate grassland under mowed and burned regimes, Ecol. Appl., 12, 1318-1328, 2002.

Chen, B., Shan, X., Shen, D., and Mou, S.: Nature of the $\mathrm{HCl}$-soluble sulfate in the sequential extraction for sulfur speciation in soils, Fresen. J. Anal. Chem., 357, 941-945, https://doi.org/10.1007/s002160050278, 1997.

Chen, H., Yang, L., Wen, L., Luo, P., Liu, L., Yang, Y., Wang, K., and Li, D.: Effects of nitrogen deposition on soil sulfur cycling, Global Biogeochem. Cy., 30, 1568-1577, https://doi.org/10.1002/2016gb005423, 2016.

Cheng, X., Luo, Y., Su, B., Verburg, P. S. J., Hui, D., Obrist, D., Arnone, J. A., Johnson, D. W., and Evans, R. D.: Responses of net ecosystem $\mathrm{CO}_{2}$ exchange to nitrogen fertilization in experimentally manipulated grassland ecosystems, Agr. Forest Meteorol., 149, 1956-1963, https://doi.org/10.1016/j.agrformet.2009.07.001, 2009.

Chiang, H. C., Lo, J. C., and Yeh, K. C.: Genes associated with heavy metal tolerance and accumulation in $\mathrm{Zn} / \mathrm{Cd}$ hyperaccumulator Arabidopsis halleri: a genomic survey with cDNA microarray, Environ. Sci. Technol., 40, 6792-6798, https://doi.org/10.1021/es061432y, 2006.

De Bona, F. D. and Monteiro, F. A.: Nitrogen and sulfur fertilization and dynamics in a Brazilian Entisol under pasture, Soil Sci. Soc. Am. J., 74, 1248-1258, https://doi.org/10.2136/sssaj2009.0228, 2010.

Dentener, F., Drevet, J., Lamarque, J. F., Bey, I., Eickhout, B., Fiore, A. M., Hauglustaine, D., Horowitz, L. W., Krol, M., Kulshrestha, U. C., Lawrence, M., Galy-Lacaux, C., Rast, S., Shindell, D., Stevenson, D., Van Noije, T., Atherton, C., Bell, N., Bergman, D., Butler, T., Cofala, J., Collins, B., Doherty, R., Ellingsen, K., Galloway, J., Gauss, M., Montanaro, V., Müller, J. F., Pitari, G., Rodriguez, J., Sanderson, M., Solmon, F., Strahan, S., Schultz, M., Sudo, K., Szopa, S., and Wild, O.: Nitrogen and sulfur deposition on regional and global scales: A multimodel evaluation, Global Biogeochem. Cy., 20, GB4003, https://doi.org/10.1029/2005GB002672, 2006.

Eriksen, J. and Askegaard, M.: Sulphate leaching in an organic crop rotation on sandy soil in Denmark, Agr. Ecosyst. Environ., 78, 107-114, https://doi.org/10.1016/S0167-8809(99)00117-6, 2000.

Feechan, A., Kwon, E., Yun, B. W., Wang, Y., Pallas, J. A., and Loake, G. J.: A central role for S-nitrosothiols in plant disease resistance, P. Natl. Acad. Sci. USA, 102, 8054-8059, https://doi.org/10.1073/pnas.0501456102, 2005.

Ghani, A., McLaren, R., and Swift, R.: Sulphur mineralisation and transformations in soils as influenced by additions of carbon, nitrogen and sulphur, Soil Biol. Biochem., 24, 331-341, https://doi.org/10.1016/0038-0717(92)90193-2,1992.

Hao, Y., Kang, X., Wu, X., Cui, X., Liu, W., Zhang, H., Li, Y., Wang, Y., Xu, Z., and Zhao, H.: Is frequency or amount of precipitation more important in controlling $\mathrm{CO}_{2}$ fluxes in the 30-year-old fenced and the moderately grazed temperate steppe?, Agr. Ecosyst. Environ., 17, 63-71, https://doi.org/10.1016/j.agee.2013.03.011, 2013.

Harpole, W. S., Potts, D. L., and Suding, K. N.: Ecosystem responses to water and nitrogen amendment in a California grassland, Glob. Change Boil., 13, 2341-2348, https://doi.org/10.1111/j.1365-2486.2007.01447.x, 2007.

Jackson, G. D.: Effects of nitrogen and sulfur on canola yield and nutrient uptake, Agron. J., 92, 644-649, https://doi.org/10.2134/agronj2000.924644x, 2000.

Janzen, H. H. and Ellert, B. H.: Sulfur dynamics in cultivated temperate agroecosystems, in: Sulphur in the Environment, edited by: Maynard, D. G., Marcel Dekker, New York, 11-43, 1998.

Johnson, D. W. and Todd, D.: Relationships among iron, aluminum, carbon, and sulfate in a variety of forest soils, Soil Sci. Soc. Am. J., 47, 792-800, https://doi.org/10.2136/sssaj1983.03615995004700040035x, 1983.

Juszczuk, I. M. and Ostaszewska, M.: Respiratory activity, energy and redox status in sulphur-deficient 
bean plants, Environ. Exp. Bot., 74, 245-254, https://doi.org/10.1016/j.envexpbot.2011.06.006, 2011.

Kertesz, M. A. and Mirleau, P.: The role of soil microbes in plant sulphur nutrition, J. Exp. Bot., 55, 1939-1945, https://doi.org/10.1093/jxb/erh176, 2004.

Koncz, P., Balogh, J., Papp, M., Hidy, D., Pintér, K., Fóti, S., Klumpp, K., and Nagy, Z.: Higher soil respiration under mowing than under grazing explained by biomass differences, Nutr. Cycl. Agroecosys., 103, 201-215, https://doi.org/10.1007/s10705015-9732-3, 2015.

Kost, D., Chen, L., and Dick, W. A.: Predicting plant sulfur deficiency in soils: results from Ohio, Biol. Fertil. Soils, 44, 10911098, https://doi.org/10.1007/s00374-008-0298-y, 2008.

Li, S., Lin, B., and Zhou, W.: Soil organic sulfur mineralization in the presence of growing plants under aerobic or waterlogged conditions, Soil Biol. Biochem., 33, 721-727, https://doi.org/10.1016/S0038-0717(00)00205-4, 2001.

Lü, X., Lü, F., Zhou, L., Han, X., and Han, X.: Stoichiometric response of dominant grasses to fire and mowing in a semi-arid grassland, J. Arid Environ., 78, 154-160, https://doi.org/10.1016/j.jaridenv.2011.11.008, 2012.

McGill, W. B. and Cole, C. V.: Comparative aspects of cycling of organic C, N, S and P through soil organic matter, Geoderma, 26, 267-286, https://doi.org/10.1016/0016-7061(81)90024-0, 1981.

Nelson, D. W. and Sommers, L.: Total Carbon, Organic Carbon, and Organic Matter, in: Methods of Soil Analysis: Part 2 - Chemical and Microbiological Properties, 2nd Edn., edited by: Miller, A. L., Keeney, R. H., and Soil, D. R., Science Society of America, Madison, 539-579, 1982.

Niknahad-Gharmakher, H., Machet, J. M., Beaudoin, N., and Recous, S.: Estimation of sulfur mineralization and relationships with nitrogen and carbon in soils, Biol. Fertil. Soils, 45, $297-$ 304, https://doi.org/10.1007/s00374-008-0332-0, 2009.

Niu, S., Wu, M., Han, Y. I., Xia, J., Zhang, Z. H. E., Yang, H., and Wan, S.: Nitrogen effects on net ecosystem carbon exchange in a temperate steppe, Glob. Change Boil., 16, 144-155, https://doi.org/10.1111/j.1365-2486.2009.01894.x, 2010.

Nodvin, S. C., Driscoll, C. T., and Likens, G. E.: The effect of $\mathrm{pH}$ on sulfate adsorption by a forest soil, Soil Sci., 142, 69-75, https://doi.org/10.1097/00010694-198608000-00002, 1986.

Phoenix, G. K., Emmett, B. A., Britton, A. J., Caporn, S. J. M., Dise, N. B., Helliwell, R., Jones, L., Leake, J. R., Leith, I. D., Sheppard, L. J., Sowerby, A., Pilkington, M. G., Rowe, E. C., Ashmore, M. R., and Power, S. A.: Impacts of atmospheric nitrogen deposition: responses of multiple plant and soil parameters across contrasting ecosystems in longterm field experiments, Glob. Change Boil., 18, 1197-1215, https://doi.org/10.1111/j.1365-2486.2011.02590.x, 2012.

Riscassi, A., Scanlon, T., and Galloway, J.: Stream geochemical response to reductions in acid deposition in headwater streams: Chronic versus episodic acidification recovery, Hydrol. Proc., 33, 512-526, https://doi.org/10.1002/hyp.13349, 2019.

Roberts, T. L. and Bettany, J. R.: The influence of topography on the nature and distribution of soil sulfur across a narrow environmental gradient, Can. J. Soil Sci., 65, 419-434, https://doi.org/10.4141/cjss85-046, 1985.

Scherer, H. W., Welp, G., and Förster, S.: Sulfur fractions in particle-size separates as influenced by long-term application of mineral and organic fertilizers, Plant, Soil Environ., 58, 242-248, https://doi.org/10.17221/78/2012-PSE, 2012.

Scherer, H. W.: Sulfur in soils, J. Plant Nutr. Soil Sci., 172, 326335, https://doi.org/10.1002/jpln.200900037, 2009.

Smith, M. D., Knapp, A. K., and Collins, S. L.: A framework for assessing ecosystem dynamics in response to chronic resource alterations induced by global change, Ecology, 90, 3279-3289, 2009.

Solomon, D., Lehmann, J., Tekalign, M., Fritzsche, F., and Zech, W.: Sulfur fractions in particle-size separates of the sub-humid Ethiopian highlands as influenced by land use changes, Geoderma, 102, 41-59, https://doi.org/10.1016/s00167061(00)00103-8, 2001.

Soon, Y. K., Kalra, Y. P., and Abboud, S. A.: Comparison of some methods for the determination of total sulfur in plant tissues, Commun. Soil Sci. Plant Anal., 27, 809-818, https://doi.org/10.1080/00103629609369598, 1996.

Tabatabai, M. A.: Chemistry of Sulfur in Soils, in: Chemical Processes in Soils, edited by: Tabatabai, M. A. and Sparks, D. L., SSSA Book Series, Soil Science Society of America, Madison, WI, 203-218, https://doi.org/10.2136/sssabookser8.c3, 2005.

Tabatabai, M. A. and Bremner, J. M.: Forms of sulfur, carbon, nitrogen and sulfur relationships in Iowa soils, Soil Sci., 114, 380 386, https://doi.org/10.1097/00010694-197211000-00009, 1972.

Tisdale, S., Nelson, W., Beaton, J., and Havlin, J.: Soil Fertility and Fertilizers, Prentice Hall, New Jersey, 251-254, 1993.

Viechtbauer, W.: Conducting meta-analyses in $\mathrm{R}$ with the metafor package, J. Stat. Softw., 36, 1-48, https://doi.org/10.18637/jss.v036.i03, 2010.

Wang, C., Butterbach-Bahl, K., He, N., Wang, Q., Xing, X., and Han, X.: Nitrogen addition and mowing affect microbial nitrogen transformations in $\mathrm{a}_{4}$ grassland in northern China, Eur. J. Soil Sci., 66, 485-495, https://doi.org/10.1111/ejss.12231, 2015.

Wang, R., Creamer, C. A., Wang, X., He, P., Xu, Z. W., and Jiang, Y.: The effects of a 9-year nitrogen and water addition on soil aggregate phosphorus and sulfur availability in a semi-arid grassland, Ecol. Indic., 61, 806-814, https://doi.org/10.1016/j.ecolind.2015.10.033, 2016.

Wang, R., Zhang, Y., He, P., Yin, J., Yang, J., Liu, H., Cai, J., Shi, Z., Feng, X., Dijkstra, F. A., Han, X., and Jiang, Y.: Intensity and frequency of nitrogen addition alter soil chemical properties depending on mowing management in a temperate steppe, J. Environ. Manage., 224, 77-86, https://doi.org/10.1016/j.jenvman.2018.07.036, 2018.

White, R. P., Murray, S., and Rohweder, M.: Pilot analysis of global ecosystems: grassland ecosystems, World Resources Institute, Washington DC, 12-13, 2000.

Williams, C. H. and Steinbergs, A.: Soil sulphur fractions as chemical indices of available sulphur in some Australian soils, Aust. J. Agr. Res., 10, 340-352, https://doi.org/10.1071/AR9590340, 1959.

Wulff-Zottele, C., Gatzke, N., Kopka, J., Orellana, A., Hoefgen, R., Fisahn, J., and Hesse, H.: Photosynthesis and metabolism interact during acclimation of Arabidopsis thaliana to high irradiance and sulphur depletion, Plant, Cell Environ., 33, 1974-1988, https://doi.org/10.1111/j.1365-3040.2010.02199.x, 2010.

Yang, H., Jiang, L., Li, L., Li, A., Wu, M., and Wan, S.: Diversitydependent stability under mowing and nutrient addition: evi- 
dence from a 7-year grassland experiment, Ecol. Lett., 15, 619626, https://doi.org/10.1111/j.1461-0248.2012.01778.x, 2012.

Yang, Z., Singh, B. R., Hansen, S., Hu, Z., and Riley, H.: Aggregate associated sulfur fractions in long-term $(>80$ Years) fertilized soils, Soil Sci. Soc. Am. J., 71, 163-170, https://doi.org/10.2136/sssaj2006.0242, 2007.

Zhang, Y., Han, X., He, N., Long, M., Huang, J., Zhang, G., Wang, Q., and Han, X.: Increase in ammonia volatilization from soil in response to $\mathrm{N}$ deposition in Inner Mongolia grasslands, Atmos. Environ., 84, 156-162, https://doi.org/10.1016/j.atmosenv.2013.11.052, 2014a.

Zhang, Y., Lu, X., Isbell, F., Stevens, C., Han, X., He, N., Zhang, G., Yu, Q., Huang, J., and Han, X.: Rapid plant species loss at high rates and at low frequency of $\mathrm{N}$ addition in temperate steppe, Glob. Change Boil., 20, 3520-3529, https://doi.org/10.1111/gcb.12611, 2014b.

Zhang, Y., Zhang, S., Wang, R., Cai, J., Zhang, Y., Li, H., Huang, S., and Jiang, Y.: Impacts of fertilization practices on $\mathrm{pH}$ and the $\mathrm{pH}$ buffering capacity of calcareous soil, Soil Sci. Plant Nutr., 62, 432-439, https://doi.org/10.1080/00380768.2016.1226685, 2016.
Zhang, Y., Loreau, M., He, N., Zhang, G., and Han, X.: Mowing exacerbates the loss of ecosystem stability under nitrogen enrichment in a temperate grassland, Funct. Ecol., 31, 1637-1646, https://doi.org/10.1111/1365-2435.12850, 2017a

Zhang, Y., Wang, J., Stevens, C. J., Lü, X., He, N., Wang, C., and Han, X.: Effects of the frequency and the rate of $\mathrm{N}$ enrichment on community structure in a temperate grassland, J. Plant Ecol., 11, 685-695, https://doi.org/10.1093/jpe/rtx041, 2017b.

Zhao, Y., Zhang, L., Chen, Y., Liu, X., Xu, W., Pan, Y., and Duan, L.: Atmospheric nitrogen deposition to China: A model analysis on nitrogen budget and critical load exceedance, Atmos. Environ., 153, 32-40, https://doi.org/10.1016/j.atmosenv.2017.01.018, 2017. 